\title{
MORPHOLOGICAL AND CYTOCHEMICAL CHARACTERIZATION OF SPORES AND GILLS OF LEPISTA SORDIDA (FUNGI: BASIDIOMYCOTA)
}

\author{
Letícia V. Graf; Ruth J. G. Schadeck*; Lucélia Donatti; Dorly F. Buchi
}

Departamento de Biologia Celular, Universidade Federal do Paraná, Curitiba, PR, Brasil.

Submitted: April 11, 2007; Returned to authors for corrections: October 20, 2007; Approved: July 14, 2008.

\begin{abstract}
Some ultrastructural and cytochemical aspects of Lepista sordida are described. Basidiospores with verruculose and irregular ornamentations were observed through scanning electron microscopy. Confocal microscopy indicated that most of them exhibited a single large lipid body, no acidic vesicles and nucleus localized in the cell periphery.
\end{abstract}

Key words: basidiospores, lipid body, confocal microscopy, electron microscopy, Lepista sordida.

Mushrooms are important for their nutritive, medicinal, economic and ecological values (8). Some species of the genus Lepista (Tricholomatacea) such as L. nuda and L. sordida have been considered edible and tasteful (10). L. nuda presents antioxidant effect (5) and antibiotic activity against many bacteria (2). Besides, $L$. sordida produces two diterpenes that induce differentiation in human leukemic cells (4). These medicinal properties demonstrate how important it is to study the cellular biology of this genus. Optical microscopy images of $L$. sordida and $L$. nuda spores showed one large round structure occupying most of the cytoplasm (12). Although extensive search in the scientific literature, no information about cytochemical properties of this structure was found. The aims of the present work were to use laser scanning confocal microscopy (LSCM) to investigate if this structure consists of lipid material and also to characterize some morphological and cytochemical aspects of $L$. sordida spores and gills.

Basidiomes of $L$. sordida were collected in lawns from the city of Curitiba, Paraná, Brazil. The freshly collected mushrooms presented a lilaceous hygrophanous pileus (results not shown). The spore print was taken and kept up to three weeks for microscopic analysis. The gills and the spores still attached to basidia were either observed through LSCM and differential interference contrast microcopy (DIC) or fixed for posterior analysis. In order to observe the surfaces through Scanning Electron Microscopy (SEM), the gills were fixed in Karnovski solution ( $2.5 \%$ glutaraldehyde, $2 \%$ p-formaldehyde, cacodylate buffer $0.1 \mathrm{M} \mathrm{pH}$ 7.2) for two hours, and then dehydrated using increasing concentrations of alcohol, critical point dried and metallized. The images were then captured using a JEOL-JSM 6360 LV scanning electron microscope. Adobe Photoshop program was used to improve the contrast of some images.

SEM indicated that the gills presented basidia surrounded by cells without basidiospores, the basidioles (Fig. 1A). The basidia were the biggest cells observed in the hymenium. They bore four ellipsoid to ovoid basidiospores (Figs. 1A-F) and measured about $5-7.2 \times 3.7-4.5 \mu \mathrm{m}$. Through SEM, it was possible to observe the details of the ornaments over most of the surface (Fig. 1B). If we consider the term verruculose to refer to ornaments with a rounded apex, most of the ones observed through SEM were verruculose (Fig. 1B). These results are in accordance with previous studies that reported spore ornamentation in $L$. sordida as verruculose to rugulose or finely rugulose (10).

Nile red vital staining provided cytochemical characterization of this structure (1). The gill slices and free spores were stained for 5 min with $5 \mu \mathrm{g} \mathrm{ml}^{-1}$ of Nile red (Sigma) and analyzed through LSCM, as described by Barbosa et al., 2006 (1). The cytoplasm of basidiospores still attached to basidia was filled with lipids, as shown by longitudinal (Figs. 1C-D) and surface views (Figs. 1E-F). In most of hymenial cells no lipid bodies were seen (Figs. 1C-E). Nearly all basidiospores analyzed three weeks after

*Corresponding Author. Mailing address: Department of Cell Biology, Federal University of Paraná, Brazil, C.P. 19031, 81531-990. P. O. Box 19088. Curitiba, PR, Brazil. Tel.: 5541361774 Fax: 554132662042. E-mail: ruths@ufpr.br 

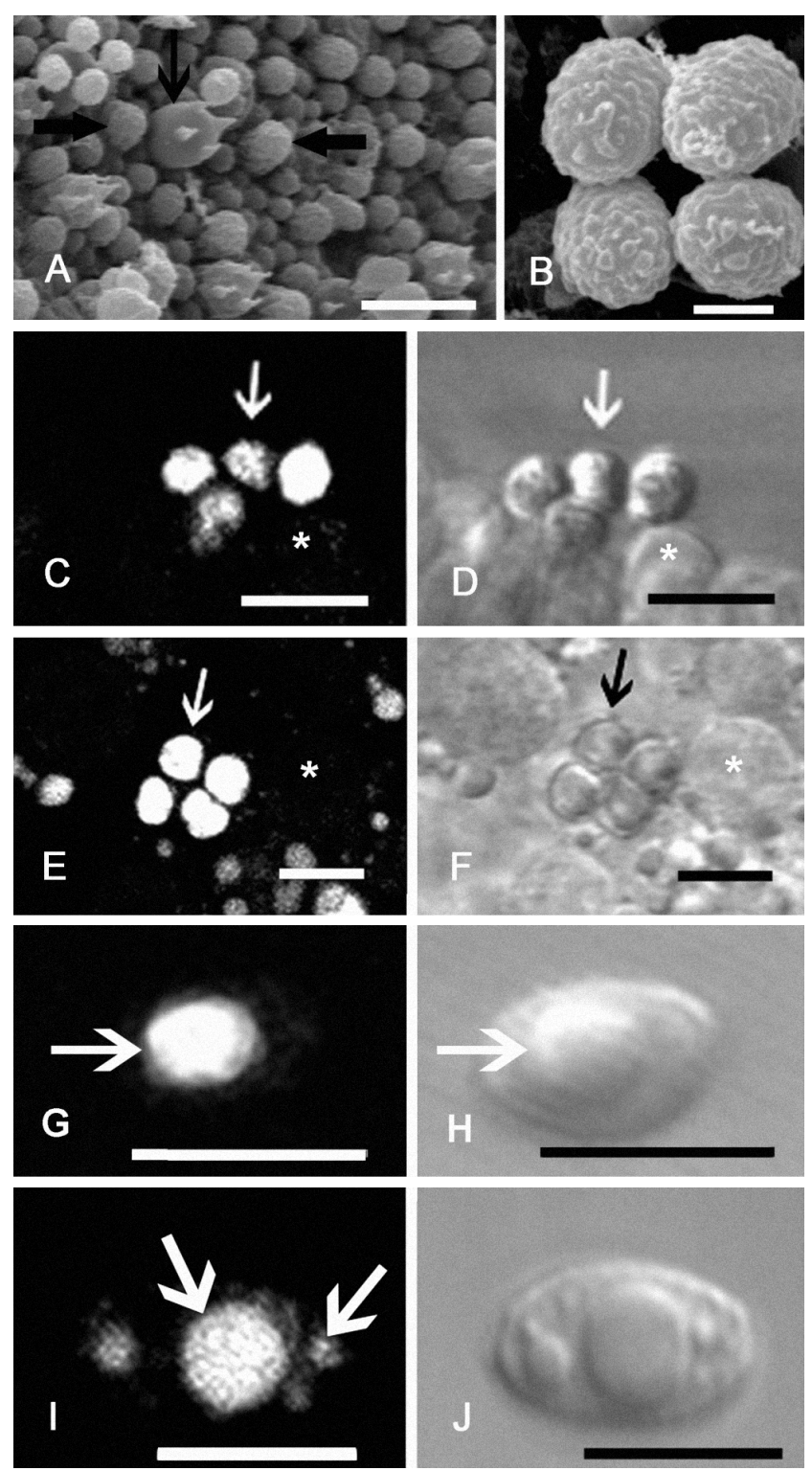

Figure 1. Hymenium morphology through SEM (Figs. A-B), Nile red staining trough LSCM (Figs. C, E, G, I) and DIC (Figs. D, F, H, J). A. Surface view with basidia (thin $\uparrow$ ) and basidioles (thick $\uparrow$ ). B. Basidiospores with ornament by a surface view. C. Transversal section of gills demonstrated a tetrad of basidiospores filled with lipids (thin $\uparrow$ ) and no staining in the other hymenial elements (*). D. The same cells observed in C. E. Surface view of a gill showing the same elements as C. Tetrads (thin $\uparrow$ ) and hymenial elements $(*)$ were observed. F. The same cells observed in E. G. Free spores three weeks after harvesting showed single lipid body $(\uparrow)$ occupying most of the cell volume. H. The same cell as observed in G. I. Free spores three weeks after harvesting showed several lipid bodies $(\uparrow)$. J. The same cell as observed in I. Bars: fig $A=10 \mu \mathrm{m}$; fig $B=2 \mu \mathrm{m}$; figs. $\mathrm{C}-\mathrm{J}=5 \mu \mathrm{m}$.
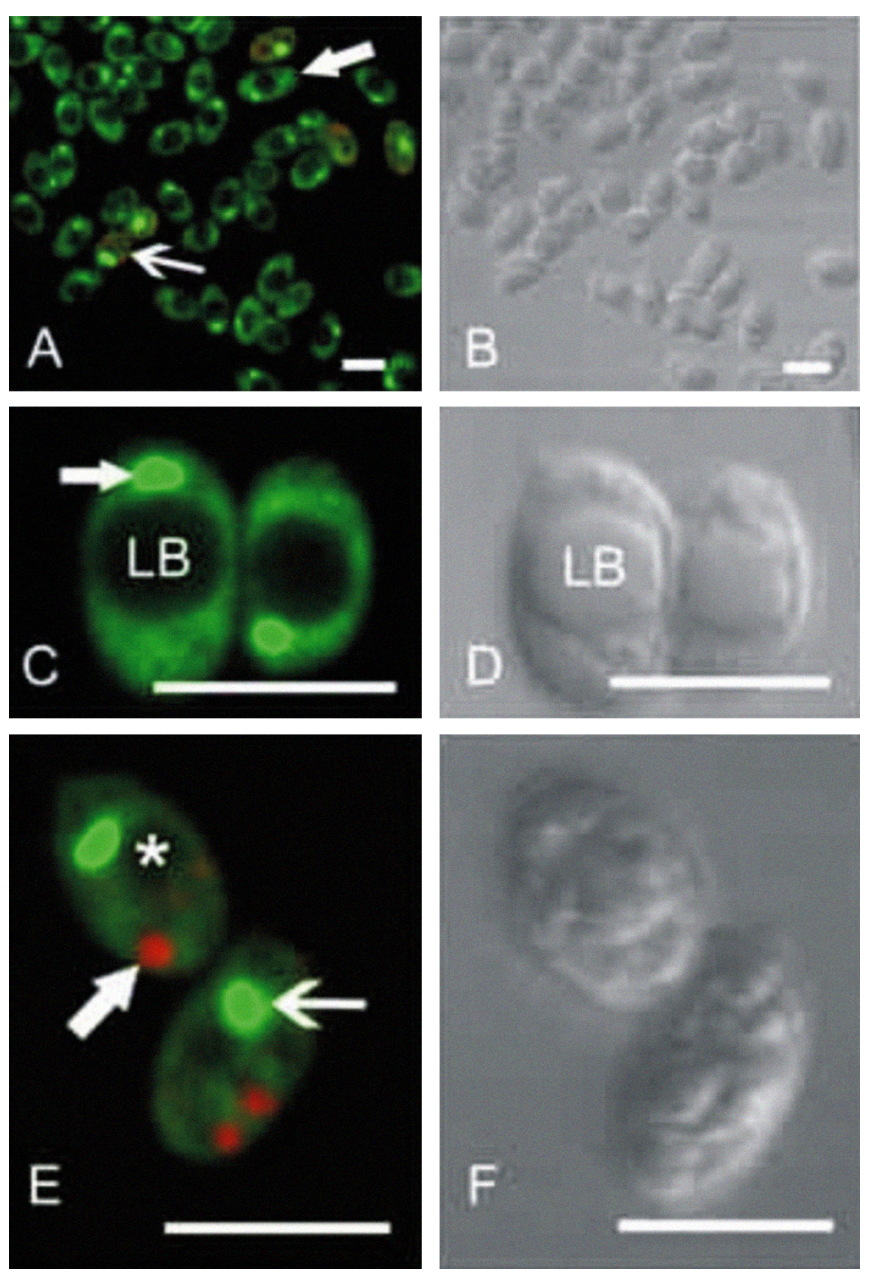

Figure 2. Nucleus and vacuoles of basidiospores three weeks after harvesting. Left column: acridine orange staining trough LSCM. Right column: DIC microscopy. A. Most basidiospores showed dark region corresponding to a big lipid droplet (thick $\uparrow$ ) and few show some small darks regions indicating small lipid bodies (thin $\uparrow$ ). B. The same cells as observed in A. C. Spores with a big dark region corresponding to a big lipid droplet (LB), a peripheric nucleus $(\uparrow)$ and no vacuoles. $D$. The same cell as observed in C. E. Basidiospores with small dark region corresponding to lipid bodies (asterisk), vacuoles (thick $\uparrow$ ) and a more centralized nucleus (thin $\uparrow$ ). F. The same cell as observed in E. Bar of all figures $=5 \mu \mathrm{m}$.

harvesting still showed a single large lipid body occupying most of the cytoplasm (Figs. 1G-H). A small number of spores contained two or more small lipid bodies (Figs. 1 I-J).

The great amount of lipid storage inside basidiospores and the little amount inside basidia (Figs. $1 \mathrm{C}, \mathrm{E}$ ) suggest that lipid bodies are gradually accumulated inside basidiospores during their formation. This hypothesis is in accordance with studies 
of other organisms such as Mortierella ramanniana var. angulispora, where the lipid bodies initially formed present smaller size than the mature ones (3). This shows that the lipid reserve must play a vital role in the fungi survival. The apparent role is chemical energy storage (6), but it may also take part in other functions, such as carbohydrate and amino acid biosynthesis through the glyoxilate cycle (7).

Besides providing information about $L$. sordida spores, the Nile red staining method was very useful to investigate lipid reserves in basidiospores. When compared to conventional chemical procedures, this method is easier, faster and avoid artifacts. Confocal microscopy, also used in the present work, is more advantageous than conventional fluorescent microscopy because produces images with better resolution. However, in the routine laboratory work, in cases when a higher resolution is not essential, a fluorescent microscope can be used to determine lipid material.

For observation of nuclei and vacuoles, the basidiospores from the spore print were incubated in $15 \mu \mathrm{g} \mathrm{ml}^{-1}$ acridine orange aqueous solution for 20 minutes and examined through LSCM, as described by Barbosa et al., 2006 (1). Under DIC microscopy, the lipid reserves could be seen as an elevated area when compared to the cytoplasm region (Figs. $1 \mathrm{H}-\mathrm{J}$ ). After staining the same material with acridine orange, the droplets appeared as a dark area (Fig. 2C). In spores that displayed one big lipid body, the nuclei were peripheric and most of them did not contain vesicles of acridine orange (Figs. $2 \mathrm{~A}, \mathrm{C}$ ). Spores that showed few and smaller lipid bodies presented a more centralized nucleus and displayed acridine orange stained vesicles (Figs.2 A, E). The acridine orange accumulated inside acidic vesicles changes the fluorescence emission from green to red, due to a concentration-dependent stacking of molecules (9). The low $\mathrm{pH}$ of lysosomes and analogous compartments is maintained by vacuolar ATPases (V-ATPases) (11). Thus, the spores with acridine orange-stained vesicles must be producing enough ATP to drive the proton pump, in order to maintain a high hydrogen ion concentration inside these compartments. This indicates that the lipid bodies play an important role in the vital metabolic activity.

\section{ACKNOWLEDGMENTS}

We thank Paraná Tecnologia and the Electron Microscopy Center of Universidade Federal do Paraná, Brazil, for the technical support; Prof. Dra. Rosa Mara B. da Silveira for the suggestions made to improve this paper; mycologist André de Meijer for species identification and for language correction of this paper; Dra. Ruth Graf for permission to collect the mushrooms in her lawn.

\section{RESUMO}

\section{Caracterização morfológica e citoquímica dos esporos e lamelas de Lepista sordida (Fungi: Basidiomycota)}

Este trabalho descreve aspectos ultraestruturais e citoquímicos de Lepista sordida. Basidiósporos recobertos com ornamentações verruculosas e irregulares foram observados através de microscopia eletrônica de varredura. Através de microscopia confocal verificou-se que a maioria apresentava um grande corpo lipídico, ausência de vesículas ácidas e núcleo localizado na periferia.

Palavras-chave: basidiósporos, corpos lipídicos, microscopia confocal, microscopia eletrônica, Lepista sordida.

\section{REFERENCES}

1. Barbosa, A.C.; Schadeck, R.J.G.; Do Carmo, A.E.; Graf, L.V.; Tomáz, R.; De Souza, C.F.; Mendes, J.; Randi, M.A.F.; Buchi, I.D. (2006). Morphology, lipid body and vacuole dynamics during secondary conidia formation in Colletotrichum acutatum: laser scanning confocal analysis. Can. J. Microbiol., 52, 117-124.

2. Dulger, B.; Ergul, C.; Gucin, F. (2002). Antimicrobial activity of the macrofungus Lepista nuda. Fitoterapia, 73, 695-697.

3. Kamisaka, Y.; Noda, N.; Sakai, T.; Kawasaki, K. (1999). Lipid bodies and lipid body formation in an oleaginous fungus, Mortierella ramanniana var. angulispora. Biochim. Biophys. Acta, 1438, 185 198.

4. Mazur, X.; Becker, U.; Anke, T.; Sterner, O. (1996). Two new bioactive diterpenes from Lepista sordida. Phytochemistry, 43, 405-407.

5. Murcia, M.A.; Martinez-Tomé, M.; Jimenez, A.M.; Vera, A.M.; Honrubia, M.; Parras, P. (2002). Antioxidant activity of edible fungi (truffles and mushrooms): losses during industrial processing. J. Food Produts, 65, 1614-1622.

6. Murphy, D.J. (2001). The biogenesis and functions of lipid bodies in animals, plants and microorganisms. Prog. Lipid Res., 40, 325-348.

7. Ruch, D.G.; Burton, K.W.; Ingram, L. (1991). An occurrence of the glyoxylate cycle in basidiospores of homobasidiomycetes. Mycologia, 83, 821-825.

8. Sánchez, C. (2004). Modern aspects of mushroom culture technology. Appl. Microbiol. Biotechnol., 64, 756-762.

9. Servais, H.; Van Der Smissenb, P.; Thiriona, G.; Van der Essena, G.; Van Bambekea, F.; Tulkensa, P.M.; Mingeot-Leclercqa, M.P. (2005). Gentamicin-induced apoptosis in LLC-PK1 cells: Involvement of lysosomes and mitochondria. Toxicol. Appl. Pharmacol., 206, 321 333.

10. Stott, K.G. (1998). Characteristics of Australian edible fungi in the genus Lepista and investigation into factors affecting cultivation. Sydney, Australia, 168p. (Dr. Philosophy. Thesis. University of Western Sidney Hawkesbury).

11. Wilkens, S.; Zhang, Z.; Zheng, Y. (2005). A structural model of the vacuolar ATPase from transmission electron microscopy. Micron., $36,109-126$.

12. Storey, M. 2006. Available at: http://www.bioimages.org.uk/HTML/ P3/P30852.HTM. Accessed 01 June 2006. 